\title{
Magyarország új nemzeti biztonsági stratégiájáról
}

\begin{abstract}
A tanulmány a 2020 áprilisában közzétett új magyar nemzet biztonsági stratégiát jellemzi, elemzi és értékeli. Az új dokumentumot - tartalmának részletes ismertetése mellett - egyrészt összeveti a nemzeti biztonsági stratégiákkal szembeni funkcionális követelményekkel, másrészt a korábbi nemzeti biztonsági stratégiával, illetve a Stratégiai Védelmi Kutatóintézetnek a magyar társadalom biztonságpercepciójára vonatkozó 2019. decemberi kutatásának erdeményeivel is.
\end{abstract}

Kulcsszavak: Magyarország, biztonság, biztonságpolitika, stratégiai dokumentum, nemzeti biztonsági stratégia

\section{Csiki Varga Tamás - Tálas Péter: On the New Hungarian National Security Strategy}

The paper offers an overview, analysis and assessment of the new Hungarian National Security Strategy adopted in April 2020. Besides a textual analysis, the new document is assessed with regard to the functionality of such strategic documents on the one hand and is compared to the previous NSS on the other. Moreover, the evaluation also encompasses a reflection upon the public opinion poll on Hungarian security perception carried out by the Institute for Strategic and Defence Studies in December 2019.

Keywords: Hungary, security, security policy, strategic document, national security strategy

\section{Bevezető}

A magyar kormány 2020. április 21-én tette közé Magyarország új, Biztonságos Magyarország egy változékony világban alcímet viselö nemzeti biztonsági stratégiáját (NBS). ${ }^{3} \mathrm{E}$ dokumentum váltotta fel hazánk 2012 februárjában elfogadott és hivatalosan több mint nyolc évig hatályban lévő korábbi nemzeti biztonsági stratégiáját. Elemzésünkben az új stratégiát mutatjuk be, jellemezzük, illetve értelmezzük, összevetve részben a korábbi nemzeti biztonsági stratégiával, részben pedig a Nemzeti Közszolgálati Egyetem (NKE) Eötvös József Kutatóközpont (EJKK) Stratégiai Védelmi Kutatóintézetének (SVKI) a magyar társadalom

Csiki Varga Tamás, a Nemzeti Közszolgálati Egyetem, SVKI tudományos munkatársa, e-mail: csiki.tamas@uni-nke.hu Tálas Péter, a Nemzeti Közszolgálati Egyetem, SVKI igazgatója, e-mail: talas.peter@uni-nke.hu

1163/2020. (IV. 21.) Korm. határozat Magyarország Nemzeti Biztonsági Stratégiájáról. [online], 2020. 04. 21. Forrás: magyarkozlony.hu [2020. 05. 20.]. 
biztonságról és fenyegetésekről alkotott véleményére vonatkozó 2019. decemberi kutatás eredményeivel. ${ }^{4}$

\section{A nemzeti biztonsági stratégiák funkciójáról}

Minden kormánypolitika arra törekszik, hogy olyan nemzeti és nemzetközi feltételeket alakítson ki, amelyek elösegítik a legfontosabb nemzeti értékek védelmét és a nemzeti érdekek minél teljesebb, sikeresebb érvényesítését. A tapasztalatok azt mutatják, hogy az ilyen politika sikerének alapfeltétele, hogy a mindenkori vezetés tisztában legyen az ország nemzetközi környezetével, a nemzetközi rendszerben elfoglalt helyével. Továbbá reálisan határozza meg az ország céljait, szövetségesi rendszerét, potenciális ellenségeit, illetve pontosan vegye számba az ország biztonságát befolyásoló vélt vagy valós fenyegetéseket, továbbá azokat a képességeket, amelyek a fenyegetések elhárításához, a kihívások kezeléséhez szükségesek. ${ }^{5}$ Egy ország nemzeti biztonsági stratégiája - amely a legfontosabb dokumentum a nemzeti stratégiák rendszerében - mindezek elsődleges, legalapvetőbb, tételes és deklaratív megfogalmazásait tartalmazó hivatalos dokumentuma. ${ }^{6}$ Egyszerübben fogalmazva: minden nemzeti biztonsági stratégia egy hivatalos kommunikációs eszköz, egy a biztonságot befolyásoló vagy befolyásolni képes különböző szintű és típusú, külső és belső szereplő felé megfogalmazott hivatalos politikai üzenet arról - az ország biztonságáért felelős szervezetek és intézmények számára pedig politikai iránymutatás arra vonatkozóan -, hogy egy adott kormányzat miként tekint a biztonságra, annak alkotóelemeire, területeire, elsősorban pedig az ezeket fenyegető tényezőkre, illetve miként - milyen elvek, értékek és koncepciók alapján, milyen eszközökkel és módszerekkel - kívánja befolyásolni ezeket. A hivatalos jelzőt nem véletlenül hangsúlyozzuk. A nemzeti biztonsági stratégiáknak - mint minden kormányzati stratégiának - kulcsfontosságú szerepe van abban, hogy az adott ország biztonsága és biztonságpolitikája iránt érdeklődő, illetve az ország biztonságpolitikáját alakító döntéshozók és döntés-előkészítők ne csupán az ország vezetésének és politikai szereplőinek napi aktuális céljai és taktikai megfontolásai alá rendelt, és általában meglehetősen különböző stílusú politikai kommunikációja alapján tájékozódjanak.

A nemzeti biztonsági stratégiákkal szemben általánosan elvárt, illetve megfogalmazott követelményeket az alábbiakban foglalhatjuk össze: a stratégia figyelme terjedjen ki az ország biztonságának és védelmének valamennyi területére; vegye figyelembe az ország potenciális ellenségeinek stratégiai és politikai céljait; az ország reális politikai, gazdasági és katonai helyzetéből és lehetőségeiből induljon ki; békeidőre vonatkozóan csak a nemzetgazdaságnak a biztonság szavatolásához legszükségesebb humán és anyagi forrásaival számoljon; vegye figyelembe az ország szövetségesi kötelezettségeit; továbbá tartalmazza az állam alapvető értékeit, érdekeit és céljait, a biztonsági környezet aktuális értékelését,

\footnotetext{
Alex Etl: The perception of security in Hungary. [online], ISDS Analyses, (2020), 3. Forrás: real.mtak.hu [2020. 05. 20.]; Alex Etl - Péter Tálas: The transformation of Hungarian security perception between 1999 and 2019. [online], ISDS Analyses, (2020), 4. 2020. 03. 04. Forrás: svkk.uni-nke.hu [2020. 05. 20.].

5 Tálas Péter: A nemzeti katonai stratégia és a magyar stratégiai kultúra. [online], Nemzet és Biztonság, 7. (2014), 2. 4. Forrás: nemzetesbiztonsag.hu [2020. 05. 24.].

6 Csiki Tamás: A stratégiai dokumentumok rendszere. [online], Nemzet és Biztonság, 1. (2008), 8. 76-81. Forrás: nemzetesbiztonsag.hu [2020. 05. 24.].
} 
különös tekintettel az érzékelt fenyegetésekre, kockázatokra és kihívásokra, illetve vegye számba az ezekre történő reagálás feladatait és eszközeit is. ${ }^{7}$ Emellett egy funkcionálisan „jó”, megalapozott és végrehajtható stratégiai dokumentumnak az alábbi jellemzőkkel és tartalmi elemekkel kell rendelkeznie:

- „A biztonsági környezet átfogó szemléletü értékelése - beleértve a kihívások, kockázatok, fenyegetések mellett a lehetőségeket is;

- Az elvárt jövőbeni »végállapot « megvalósításához szükséges előíró szemlélet;

- A célok - eszközök - végrehajtók - végrehajtási módszerek egysége;

- Konkrét tervezési célok azonosítása;

- A tervezési időszak erőforrásainak pontos azonosítása és ütemezése."

A következőkben elemzésünk is e kritériumok alapján értékeli az új magyar nemzeti biztonsági stratégiát, számos ponton összevetve azt a 2012-es NBS-sel.

\section{A nemzeti biztonsági stratégia világképe}

Az új nemzeti biztonsági stratégia a nemzetközi biztonsági trendeket, folyamatokat figyelembe véve megalapozottan méri fel Magyarország helyzetét a nemzetközi rendszerben, világképe pedig reálpolitikai, amely számításba veszi a különböző szereplők hatalmi képességeit és lehetőségeit. Mint azt 1. pontja is rögzíti, „az új kihívások alapja a formálódó, többpólusú világrend, a nemzetközi szereplők kapcsolatait befolyásoló szabályok átalakítására való törekvés, a biztonsági kihívások változó arculata”, miközben „biztonsági környezetünk változásai olyan gyorsak, mélyrehatóak és alapvetőek, hogy egy új világrend kialakulásáról beszélhetünk". Így e formálódó világrendnek általános értelemben az egyik leginkább meghatározó jellemzője, hogy „a biztonságunkat befolyásoló folyamatok kialakulása, fejlődésük és hatásuk nehezen jelezhető előre, és ez növekvő bizonytalanságot eredményez”, ${ }^{10}$ és „fokozatosan erősödik a különböző globális és regionális hatalmi centrumok közötti versengés". ${ }^{11}$

A stratégia világképével, illetve jövőképével kapcsolatban meghatározó, hogy a globális biztonsági helyzet romló tendenciájával, ${ }^{12}$ biztonsági környezetünk jellemzőinek fokozatos romlásával számol, „amelynek fő elemei: a váratlanság, a változékonyság, az összetettség, a hatalmi centrumok közötti növekvő versengés, a globális közjavak újraosztásának szándéka, a klímaváltozás, a szükebb régiónk geostratégiai kihívásai stb." ${ }^{13}$ - amely tényezők összességében arra sarkallják a kormányzatot, hogy rugalmas megelőzési és reagálási képességeket alakítson ki számos területen.

\footnotetext{
Csiki (2008) i. m. 77-78.

Csiki Tamás: Az új Nemzeti Katonai Stratégia a nemzetközi tapasztalatok tükrében. [online], Nemzet és Biztonság, 7. (2014), 2. 47. Forrás: nemzetesbiztonsag.hu [2020. 05. 24.].

1163/2020. (IV. 21.) Korm. határozat 45. pont.

1163/2020. (IV. 21.) Korm. határozat 2. pont.

1163/2020. (IV. 21.) Korm. határozat 47. pont.

1163/2020. (IV. 21.) Korm. határozat 47. pont.

1163/2020. (IV. 21.) Korm. határozat 44. pont.
} 
Ugyancsak reális a helyzetértékelés az ország geostratégiai adottságaival kapcsolatban, és e tekintetben olyan fontos történelmi tanulságokat rögzít, amelyek korábban a magyar stratégiai gondolkodásban formalizáltan kevésbé voltak jelen (ellentétben például a lengyel vagy cseh stratégiai diskurzussal). Így rámutat arra, hogy „a Kárpát-medence történelmi távlatokban is a nagyhatalmak hagyományos ütközőterében helyezkedett el"14 - és jegyezzük meg: e jellemző a 21. században is fennmaradt -, valamint, hogy „geostratégiai helyzetünk egyedülálló lehetőségeket biztosít számunkra, ugyanakkor biztonsági szempontból sebezhetővé tesz bennünket". ${ }^{15}$ Ezeket a sebezhetőségeket a stratégia számos pontban részletezi (lásd később).

A dokumentum helyesen reflektál a multilaterális szövetségi rendszer messzemenő jelentőségére, ami Magyarország kisállami ${ }^{16}$ jellemzőiből ered, ugyanis „,az alapvető biztonsági kihívásokra elsősorban nemzetközi együttműködés keretében, szövetségi rendszer tagjaként” vagyunk képesek reagálni, miközben „hazánk biztonságát és nemzetközi érdekérvényesítési képességét erősíti, lehetőségeit jelentősen bővíti szövetségesi és európai uniós tagállami státusunk". ${ }^{17}$ Tehát mind a közös cselekvési képesség, mind a magyar érdekképviselet magasabb szinten történő megjelenítése alapvető jelentőségü az ország számára a 21. században. A korábbi stratégiákhoz hasonló a katonai fenyegetettség érékelése, amely szerint: „Magyarország vagy szövetségesei ellen irányuló fegyveres támadás jelenleg kevéssé valószínü, de a romló általános biztonsági környezetben és egyes szomszédos régiók biztonságának nagyfokú törékenysége miatt nem lehet figyelmen kívül hagyni a hagyományos konfliktusok kialakulásának, vagy váratlan támadás bekövetkezésének lehetőségét Magyarország közvetlen környezetében sem, ideértve a szövetségeseinket érő, az Északatlanti Szerződés 5. cikke hatálya alá tartozó helyzeteket is." ${ }^{18}$ Nem véletlen, hogy a továbbiakban a stratégia szerzői határozottan kiálltak a NATO biztonsági garanciák, a kollektív védelem, valamint az európai együttmüködés mellett.

Különösen fontos lehet ez a szövetségesi védőháló olyan esetekben, amikor a kisállamok önmagukban kiszolgáltatottabbak - például a nagyhatalmak lényegesen nagyobb hatalmi képességeivel szemben -, vagy egyedül nem lennének képesek a nemzetközi folyamatokat befolyásolni. Ilyen terület a nemzetközi jog és a nemzetközi együttmüködési (például fegyverzet-ellenőrzési és -korlátozási) rezsimek működésének megsértése és még inkább a katonai konfliktusok. Erre a stratégia is rátapint az elmúlt évtized eseményei nyomán, utalva a 2014-es ukrajnai eseményekre: „A nemzetközi jogot figyelmen kívül hagyó nagyhatalmi törekvések Európa és közvetve hazánk biztonságát is megkérdőjelezhetik", miközben úgy értékel, hogy „felértékelödött a biztonság katonai eleme”. ${ }^{19}$ A fejlemények tükrében ez logikus hangsúlyváltás a 2012-es dokumentumhoz képest, amely már akkor is

\footnotetext{
1163/2020. (IV. 21.) Korm. határozat 19. pont.

1163/2020. (IV. 21.) Korm. határozat 23. pont.

16 E megnevezésben nem csupán a bibói hagyományra (vö. Bibó István: A kelet-európai kisállamok nyomorúsága. Bibó István munkái V. Budapest, Argumentum Kiadó és Nyomda Kft., 2011.) utalunk, hanem az ország hatalmi képességeire és reálpolitikai súlyára, viszonyítási pontként a térség középhatalmára, a közel 38 millió lakosú, 120 ezer fős haderővel rendelkező és a magyar védelmi kiadások ötszörösét költő Lengyelországra tekintve.

7 1163/2020. (IV. 21.) Korm. határozat 21-22. pont.

18 1163/2020. (IV. 21.) Korm. határozat 51. pont.

19 1163/2020. (IV. 21.) Korm. határozat 51-52. pont.
} 
jelezte: „a 21. században a biztonság katonai szegmense is új hangsúlyokkal jelenik meg”. ${ }^{20}$ A nagyobb figyelmet és erősebb hangsúlyt az is indokolja, hogy a stratégia készítői reálisan látják: változnak a konfliktusok jellemzői, és a 2020-as években a nagyfokú interdependencia következtében az aszimmetrikus és hibrid konfliktusok mind állami, mind nem állami szereplők részvételével és nem csak katonai eszközökkel zajlanak majd. Ezen túlmenően fel kell készülni olyan esetekre is, amikor nem egyértelmüen a fegyveres harchoz, a háborús küszöb formális átlépéséhez kötődnek ezek a konfliktusok, azaz egy például a nemzetközi jog által nem egyértelműen szabályozott vagy nem értelmezhető „szürke zónában” zajlanak. ${ }^{21}$

Ebben a világképben a stratégia Magyarország biztonsági helyzetét jelenleg szilárdnak értékeli, és a korábbi dokumentumokhoz hasonlóan deklarálja, hogy „Magyarország egyetlen országot sem tekint ellenségének”, és a „felmerülő vitáskérdések az Egyesült Nemzetek Alapokmányának céljaival, alapelveivel és a nemzetközi joggal összhangban, tárgyalásos úton" kívánja rendezni, valamint - ilyen egyértelmüen deklarált formában új elemként - kijelenti azt is, hogy „Magyarország nem fejleszt robusztus stratégiai támadó kapacitásokat".22 Minderre biztonsági környezetünkben biztonság- és bizalomerősítő intézkedésként tekinthetünk, és ismételten a stratégiai gondolkodásra mutat rá.

\section{A stratégia biztonságértelmezése}

A korábbi stratégiákhoz hasonlóan és a 21. század kihívásainak megfelelően az NBS biztonságértelmezése átfogó. Mint azt a 8. pont tételesen is rögzíti: „Magyarország és a magyar állampolgárok mindenoldalú - politikai, gazdasági, pénzügyi, társadalmi, technológiai, környezeti, egészségügyi, katonai, rendészeti, információs és kibertérbeli - biztonsága", illetve az e dimenziókban megjelenő kihívások és fenyegetések elleni védekezés, az ezekkel szembeni felkészülés képezi a tárgyát.

A stratégia földrajzi fókusza e kihívások tekintetében Magyarország közvetlen biztonsági környezete, azaz a Kárpát-medence és Közép-Európa, amin túlmenően a stabilitás kivetítése a cél a Nyugat-Balkánon, Kelet-Európában, a Közel-Keleten és a Száhel-övezetben. ${ }^{23}$ Az ország nemzetközi hatalmi képességeire tekintettel ez a fókusz racionális és indokolt - egyúttal nagymértékben lefedi azokat a kihívásokat is, amelyek közvetve befolyásolhatják biztonságunkat. Szélesebb értelemben természetesen számol azokkal a nemzetközi kihívásokkal is, amelyek globálisak (globális éghajlatváltozás, nemzetközi gazdasági rendszer), vagy jellegükből adódóan nem köthetők földrajzi tér(ségek)hez (kibertér).

\footnotetext{
20 1035/2012. (II. 21.) Korm. határozat Magyarország Nemzeti Biztonsági Stratégiájáról, 3. pont [online], 2012. 02. 21. Forrás: kormany.hu [2020. 05. 24.]

${ }_{21} 1163 / 2020$. (IV. 21.) Korm. határozat 46. pont.

22 1163/2020. (IV. 21.) Korm. határozat 12., 55., 90. pont.

$231163 / 2020$. (IV. 21.) Korm. határozat 85. pont.
} 


\section{A nemzeti szuverenitás mint alapelem}

A 2020-as NBS minden korábbinál nagyobb hangsúlyt fektet a nemzeti szuverenitásra, amelyet „önállóság és szabad cselekvési képesség” értelmezésben, a nemzetértelmezéssel szoros összefüggésben használ, és alapértékként emel be az új stratégiába: „Nemzeti szuverenitásunk olyan megkérdőjelezhetetlen alapérték, amely természetes módon van jelen hazánk kül- és belpolitikájában egyaránt. Elsődleges biztonságpolitikai érdekünk a folyamatosan változó viszonyok között a magyar állam önrendelkezésének, cselekvési szabadságának oltalmazása, megőrzése és erősítése." ${ }^{24}$ Az ebből következő és az elmúlt években a kormánypolitikában jól láthatóan képviselt érdekviták is megjelennek a dokumentumban, mind a (magyar) nemzeti szuverenitást kiterjesztve értelmezve a határon túli magyarok érdekvédelmével, mind a szuverenitásmegosztás gyakorlatával ellentétesen az Európai Unión belüli politikai vitákkal kapcsolatosan. Ebből egyértelmüen arra következtethetünk, hogy e gyakorlat a következő évtizedben is a magyar szomszédság-, illetve Európa-politika alapeleme lesz. Az érzékelt kihívások és fenyegetések (lásd később) terén konkrét példák is alátámasztják a nemzeti szuverenitás védelmének célját, így például nevesítetten ide kapcsolódik az európai bevándorláspolitika és menekültügyi szabályozás ügye: „[H]azánk nemzeti szuverenitásával ellentétesnek és elfogadhatatlannak tart bármely olyan törekvést, amely hontalanok vagy külföldi állampolgárok kötelező betelepítését írja elő." ${ }^{25}$

\section{A stratégia nemzetértelmezése}

A stratégia fenntartja azt a helyes gyakorlatot, hogy - széles, kultúrnemzeti értelemben - az országban élö és külhoni magyarokat átfogóan tekinti a magyar nemzet részének, rámutatva arra, hogy „biztonságos és sikeres Magyarország megteremtése a nemzet egészének erőfeszítését és együttműködését, valamint magyar anyanyelvünk és kultúránk megőrzését igényli határainkon innen és túl". ${ }^{26}$ Sőt, a nemzeti szuverenitás központi szerepének erősítésével és a külhoni magyarok közjogi helyzetének változásával (a magyar állampolgárság megszerzésének 2011 óta fennálló kiterjesztésével) erősödött a nemzetértelmezés „politikai nemzet” jellege, ami az értékek és érdekek szintjén úgy jelenik meg, hogy a magyar kormány erősebb kapcsolatot kíván kialakítani a külhoni magyarokkal és szükség (például a kisebbségi jogok védelme) esetén helyzetükre is igyekszik közvetlen hatást gyakorolni. Mint arra a stratégia több pontja - az Alaptörvénnyel szoros összhangban - rámutat, „kiemelt felelősséget érzünk a határon túli magyar közösségek szülőföldjükön történő boldogulásának előmozdítása [iránt]”, ugyanis „a határon túli magyarság helyzete elválaszthatatlan Magyarország biztonságától”. Ezért „biztosítani kell a határon túli magyarság alapvető jogainak védelmét. [...] Magyarország kiemelt figyelemmel követi a szomszédos államokban élő magyarok helyzetének alakulását. [...] [annak érdekében, hogy] [...] élvezhessék az önkormányzatiság és az autonómia sajátos helyzetüknek

\footnotetext{
1163/2020. (IV. 21.) Korm. határozat 8. pont.

1163/2020. (IV. 21.) Korm. határozat 9. pont.

1163/2020. (IV. 21.) Korm. határozat 4. pont.
} 
leginkább megfelelő formáit."27 Ezek a pontok egyértelműen kijelölik a szomszédságpolitika legkritikusabb „vörös vonalait”28 és ambícióit is - amelyek megvalósítása esetében a konfliktusos kikényszerítés, vagy az együttműködő megegyezés eszközei is rendelkezésre állnak a következő évtizedben.

\section{Szövetségesek, partnerek és más külső szereplők}

Az új NBS strukturáltan és jól azonosítható minőségi különbségtételekkel tekinti át Magyarország szövetségeseit és partnereit, valamint általánosságban a külső szereplőkhöz füződő viszonyrendszerét. Több mint 20 éves NATO- és 15 éves EU-tagságunk nyomán „természetes”, hogy a dokumentum szerint is „Magyarország biztonság- és védelempolitikájának elsődleges nemzetközi keretét a NATO és EU tagsága jelenti. Érdekünk a két szervezet kohéziójának megőrzése és egymást kölcsönösen erősítő és kiegészítő együttmüködése." Ugyancsak következetes fenntartása a 2012-es NBS-ben foglaltaknak, hogy „biztonságunkhoz hozzájárul az összeurópai (EBESZ) és a páneurópai (ET) keretekben megvalósuló nemzetközi együttmüködés is". ${ }^{29}$ Mindez jól mutatja, hogy az egyoldalú cselekvés helyett a multilaterális nemzetközi szervezetekben való érdekérvényesítés az ország számára kijelölt - és képességei alapján járható - út a következő évtizedben is.

Bár egyes aktuálpolitikai vitás kérdések lehetőséget adnak a kritikára, de a hosszú távú stratégia egyértelmüen leszögezi, hogy „kiemelt célunk a NATO és EU kohéziójának megőrzése”, valamint a biztonság és védelem területén „a hatékony többnemzeti együttmüködés kialakítása, amelynek kereteit a meglévő kollektív és kooperatív biztonsági rendszerek" képezik. ${ }^{30} \mathrm{E}$ tekintetben a hagyományos katonai kihívások esetében továbbra is célkitüzés marad, hogy „a haderő fejlesztésének eredményeként számottevően járulunk hozzá az Észak-atlanti Szerződés 5. cikke által szavatolt kollektív védelemhez", és nyitottan fogalmaz az Európai Unió közös biztonsági és védelmi képességfejlesztésével kapcsolatban is, miszerint: „Fontosnak tartjuk a Lisszaboni Szerződés 42.7. cikkében rejlő lehetőségeket” (bővebben lásd lejjebb). A nem katonai kihívásokkal kapcsolatban ugyancsak a szövetségesi közös fellépés a reális célkitűzés, miszerint: „Érdekeltek vagyunk a NATO és az EU nem hagyományos támadásokkal szembeni ellenálló és reagáló képességének fejlesztésében" 31 - amihez a korábbi stratégiákhoz képest sokkal nagyobb hangsúllyal, a nemzeti önerö ${ }^{32}$ több konkrét területen történő fejlesztését is elöírja a 2020-as NBS.

27 1163/2020. (IV. 21.) Korm. határozat 13., 84., 127. pont.

28 Így például a 88. pont konkrétan nevesíti az Ukrajnával fennálló helyzetet: „Magyarország érdekelt egy erős, demokratikus, stabil, gazdaságilag fejlődő Ukrajnában és kiegyensúlyozott kétoldalú kapcsolatokban, ugyanakkor az ukrán nemzettudat erősítését szolgáló legitim törekvések nem járhatnak a kárpátaljai magyar közösség szerzett jogainak csorbulásával."

29 1163/2020. (IV. 21.) Korm. határozat 91. pont.

30 1163/2020. (IV. 21.) Korm. határozat 129. pont.

31 1163/2020. (IV. 21.) Korm. határozat 129. pont.

32 A nemzeti önerő fejlesztését az alábbi területeken írja elő a stratégia: „A nemzet megóvásához szükséges feladatok teljesítése érdekében, továbbá a szövetségi rendszerek kollektív védelmi, válságkezelési vagy nemzetközi biztonsági együttmüködési tevékenységében való részvételhez, hozzájárulásaink biztosításához megfelelő nemzeti önerőre van szükség a honvédelem, a rendvédelem, a katasztrófavédelem és a terrorelhárítás területén egyaránt." (26. pont.) 


\section{NATO-szerepvállalás}

Mint azt a korábbi stratégiai dokumentumokban visszatérő elemként látjuk, az új NBS a NATO-t továbbra is mint „Magyarország biztonságának sarokkövét” határozza meg, és hangsúlyozza, hogy szoros transzatlanti kapcsolatban és a NATO kohéziójának megörzésében vagyunk érdekeltek. ${ }^{33}$ A stratégia számos más elemében is erős „NATOkonformitást” mutat, megfelelő jelzésértékkel. Így a magyar kormány magáénak vallja a NATO „360 fokos kitekintését”, tehát nem kíván priorizálni „keleti” vagy „déli” stratégiai irányokból érzékelt fenyegetések között, hanem a lehető legteljesebb spektrumú szövetségi felkészülést igényli.

Ugyancsak visszatérő elem a korábbi dokumentumokhoz képest, hogy „az euroatlanti biztonság aktív és hiteles hozzájárulói maradjunk a jövőben is", ezúttal azonban ehhez gyakorlati iránymutatás is kapcsolódik, ugyanis reagálókész, békeidőben hiteles elrettentést, válsághelyzetben vagy kollektív védelmi műveletben hatékony védelmet és segítségnyújtást kifejteni képes haderő fenntartását, ennek alátámasztására pedig 2024-től a bruttó hazai össztermék évi legalább $2 \%$-ának felhasználását rögzíti. ${ }^{34}$

Végül, de nem utolsósorban a NATO kibervédelmi politikájának formális „beemelése” is megtörtént a magyar stratégiába: „Magyarország a fizikai biztonságot veszélyeztető vagy jelentős anyagi károk okozására képes kiberképességeket fegyvernek, alkalmazásukat fegyveres agressziónak tekinti, amelyre a fizikai térben megvalósuló válaszadás is lehetséges." ${ }^{35}$ Ez a gyakorlatban megfelel a NATO-tagállamok által a 2014-es walesi csúcstalálkozón elfogadott értelmezésének, ${ }^{36}$ a szövetséghez hasonlóan nyitott opcióként definiálva a válaszadás „kiber” vagy „fizikai” jellegét.

\section{Kapcsolat az Európai Unióval}

Általános világképéhez hasonlóan a stratégia reálisan értékeli, hogy Magyarország geostratégiai helyzetéből és adottságaiból eredően európai szövetségeseivel együttmüködve lehet képes eredményesen szembenézni a nemzetközi rendszer azon kihívásaival, amelyek meghaladják a nemzetállamok reagálási képességét. Ahogy a 95. pont fogalmaz: „Magyarország erős és egységes, sikeres integrációs pályán maradó és vonzó integrációs perspektívát kínáló Európában érdekelt, mivel földrészünk csak gazdasági és katonai erejét egyesítve maradhat versenyképes az átalakuló világrendben.”

Az Európai Unióhoz füződő viszonyban az új NBS két lényegi dimenzióban határozza meg a magyar érdekeket, amelyek azonban az NBS erős nemzeti szuverenitás-központúságából eredően bizonyos önellentmondást hordoznak magukban. Az első ilyen dimenzió az EU működéséről és jövőjéről alkotott elképzelés, amely szerint „az erős Európa talapzatát a szabad nemzetek és a cselekvőképes államok képezik. Az EU jövőjét hazánk ezért nem

1163/2020. (IV. 21.) Korm. határozat 14., 92. pont.

1163/2020. (IV. 21.) Korm. határozat 5., 27. pont.

1163/2020. (IV. 21.) Korm. határozat 101. pont.

36 Csiki Tamás - Tálas Péter - Varga Gergely: A NATO walesi csúcstalálkozójának napirendje és értékelése. [online], Nemzet és Biztonság, 7. (2014), 4. 121. Forrás: nemzetesbiztonsag.hu [2020. 05. 24.]. 
föderációként, hanem szuverén nemzetállamok szövetségeként és integrációjaként képzeli el, miközben egyetért azzal, hogy ezen államok szuverenitásuk egy körülhatárolt részét nemzeti érdekből közösen gyakorolják." ${ }^{37}$ Ugyanakkor a második dimenzióban perspektivikusan az európai védelmi együttmüködés elmélyítését is felveti, ami azonban „védelmi unió" formában nem jöhet létre pusztán nemzetállamok szövetségeként. Ezt a stratégia a rövid távú realitás és a hosszú távú lehetőség szétválasztásával hidalja át - bár ebben a formában nem látható az érdekek koherenciája: „[A] folyamat hosszútávon, a tagállamok teljes egyetértése esetén elvezethet a közös európai védelemhez, egy közös európai haderő felállításához. Addig azonban meg kell őrizni az európai biztonsági és védelmi együttmüködéskormányközi jellegét."38

Az EU védelmi képességeinek általános erösítése mellett is állást foglal az NBS (fenntartva a NATO kollektív védelmének elsődlegességét), aminek ugyancsak elengedhetetlen előfeltétele „az európai védelmi képességek összehangolt fejlesztése és az uniós védelmi együttmüködés elmélyítése” annak érdekében, hogy „az EU képes legyen a közös védelemre és az önálló, hatékony nemzetközi válságkezelésre, érdemben kiegészítve a NATO tevékenységét”. ${ }^{9}$

\section{Nemzetközi partnerek}

Nem feltétlenül tekinthető priorizált sorrendnek, mégis a stratégiában felsorolt partnerek sora a következőképpen alakul: ${ }^{40}$ a visegrádi országok, Németország, Lengyelország, Amerikai Egyesült Államok, Olaszország, Franciaország, Törökország. Az egész dokumentumban lényegesen nagyobb hangsúllyal jelenik meg a közép-európai politikai - sőt ezúttal a védelmi - együttmüködés, mint a korábbiakban, így, ha sorrendnek tekintjük a partnereket, a V4-ek elsősége logikusnak tünik, mint ahogy a gazdasági és Európa-politikai szempontból leginkább meghatározó Németország helye is. Az Egyesült Államokat, amellyel minden korábbi dokumentum látványosan kiemelte a „stratégiai partnerséget” (mint térségünk legtöbb állama), így harmadikként említi - azonban ezt a magyar kül- és biztonságpolitikában érdemes úgy tekinteni, hogy a 2020-as évekre „nem Washington értékelődött le, hanem Berlin és Varsó szerepe erősödött meg", hiszen a kétoldalú védelempolitikai együttműködés az Egyesült Államokkal dinamikusan és olajozottan müködik.

Az sem mellékes tényező, hogy a kiemelten felsorolt országokkal a védelempolitikai együttmúködés valamilyen dimenziójában, plusz legalább egy, a kiemelt magyar stratégiai célokkal egyezö területen találunk érdekegyezést és együttmüködést. Így Olaszország a Földközi-tenger és Észak-Afrika térségében a gyenge államok és a migráció, Franciaország az Európa-politika (kiemelten az agrárpolitika), Törökország pedig a Közel-Kelet és a migráció viszonyrendszerében meghatározó szereplő. Ezzel párhuzamosan Olaszországgal két évtizedes strukturált katonai együttmüködésre tekinthetünk vissza a Többnemzeti Szárazföldi Kötelék (Multinational Land Force, MLF) és az Olasz-magyar-szlovén EU

\footnotetext{
1163/2020. (IV. 21.) Korm. határozat 96. pont.

1163/2020. (IV. 21.) Korm. határozat 94. pont.

1163/2020. (IV. 21.) Korm. határozat 93. pont.

1163/2020. (IV. 21.) Korm. határozat 109-115. pont.
} 
Harccsoport kapcsán; Franciaország - Németországhoz hasonlóan, bár jelenleg jóval kisebb mértékben - a Magyar Honvédség haditechnikai modernizációjában partner (az Airbus légi járművek beszerzése kapcsán), míg Törökországgal gyalogságiharcjármü-beszerzés a védelempolitikai együttmüködés közös pontja.

\section{Közép-Európa és a V4}

Kiemelt szerepéből adódóan érdemes külön is figyelmet fordítani közvetlen térségünkre, amellyel kapcsolatban az NBS a közös múltat, adottságokat és érdekeket emeli ki az együttműködés alapjaként: „Meggyőződésünk, hogy Közép-Európát nemcsak történelmi és kulturális értelemben, hanem politikai és gazdasági területen is számos sajátos közös érdek füzi össze. Célunk, hogy aktívan közremüködjünk e természetes egységet képező térség még szorosabb összekapcsolásában, elsődlegesen a Visegrádi Együttmüködés (V4) és más többnemzeti formáció és regionális képességfejlesztési kezdeményezéskeretében." ${ }^{41}$ Sőt, ebben a közegben kifejezetten védelempolitikai téren ambiciózus célokat is megfogalmaz a dokumentum, amelyek a V4 együttmüködés elmúlt tíz évének gyakorlati eredményére támaszkodhatnak: „Hazánk érdeke, hogy szem előtt tartva a magyar biztonságpolitikai prioritásokat és a fenyegetések súlyosságát, részt vegyen, vagy vezető szerepet töltsön be regionális szinten a többnemzeti formációkban és képességfejlesztési kezdeményezésekben." ${ }^{\$ 2}$ Ez a törekvés pedig a kétoldalú és regionális együttmüködés erösítésének szándékával ötvözve többször ismétlődik (a 108., 130., 141. pontokban), egyrészt általánosan a többnemzeti képességfejlesztés és a védelmi formációk vonatkozásában, másrészt konkrétan a Magyarországon a közelmúltban létrehozott regionális különleges műveleti parancsnokság és közép-európai hadosztály-parancsnokság tekintetében.

\section{Külgazdasági fókusz}

Miként a stratégia egészének erős gazdaságpolitikai dimenziója van, a külkapcsolatokban is megjelenik a gazdasági kapcsolatok további szélesítésének és mélyítésének szándéka. A magyar gazdaság nagyfokú globalizáltsága és exportorientáltsága miatt az a célkitüzés, hogy „Valamennyi érdekelt állammal képes legyen politikai és gazdasági együttműködést folytatni”, a 2020-as években sem változhat. Annak pedig szintén üzenetértéke van, hogy „külgazdasági törekvéseinkben nagy jelentőséget tulajdonítunk kapcsolataink szorosabbra füzésének a posztszovjet térségbeli, közel-keleti, ázsiai, afrikai és latin-amerikai országokkal és regionális szervezetekkel. [S]zem előtt tartjuk a szövetségesi és az európai uniós szolidaritást, ugyanakkor nem támasztunk ideológiai jellegủ előfeltételeket." ${ }^{43}$ E gazdasági érdekek hangsúlyosan jelennek meg a transzatlanti szövetségi rendszerben sokak által óvatos vagy nyílt kritikával illetett, egyes dimenziókban nyíltan a konfliktusos kapcsolatot is felvállaló két külső nagyhatalom, Oroszország és a Kínai Népköztársaság vonatkozásában is.

\footnotetext{
1163/2020. (IV. 21.) Korm. határozat 16. pont.

2 1163/2020. (IV. 21.) Korm. határozat 97. pont.

$431163 / 2020$. (IV. 21.) Korm. határozat 131. pont.
} 


\section{Oroszország}

Oroszországgal az NBS két pontja foglalkozik - a 118. nevesítve, az 52. pedig „hallgatólagosan”. Az „üzenetek” itt is jól érthetők, hiszen a dokumentum elismeri azt a nagyhatalmi szerepet, ami Oroszországnak presztízsértékü: „Az Oroszországi Föderáció a nemzetközi rendszer egyik meghatározó tényezője, számos globális és regionális biztonsági kérdés kezelésében játszik megkerülhetetlen szerepet. A közelmúltban ugyanakkor a NATO és Oroszország, valamint az EU és Oroszország kapcsolatában súlyos feszültségek alakultak ki." Ez kiegészül a NATO- és EU-konform narratívával, miszerint Oroszországgal „kettős megközelítést” kell fenntartani szövetségi szinten: „Ezzel együtt a politikai párbeszéd csatornáit is nyitva hagyta, mivel a Szövetség nem keresi a konfliktust és nem is jelent fenyegetést Oroszország számára. Ebben a helyzetben az Oroszországgal folytatott politikai párbeszédre és a kockázatokat csökkentő, a bizalmat erősítő intézkedésekre különösen nagy szükség van." Így a szövetségi szinten szükséges feszültségcsökkentő intézkedések támogatásán belül egyértelmüen kirajzolódik a magyar álláspont, amely elsősorban nem biztonsági fenyegetésnek, hanem potenciális gazdasági partnernek tekinti Oroszországot: „Magyarország - miközben prioritásnak tartja a NATO és az EU kohéziójának megőrzését - érdekelt a magyar-orosz kapcsolatok és gazdasági együttmüködés pragmatikus fejlesztésében." ${ }^{4}$

A NATO-konformitást erősíti a biztonsági környezet értékelésével foglalkozó 52. pont, amely ugyan nem nevesíti Oroszországot, de a leírt cselekményből felismerhetők a 2014-es és azt követő ukrajnai események és azok általános hatásai. Tekintettel arra a stratégiai sokkra, amit Oroszország ukrajnai agressziója és asszertív európai fellépése jelentett, bölcs meglátás a katonai erő használatához és a nemzetközi jog kisállamok számára nyújtott garanciáihoz kapcsolódó nézetek felülvizsgálata. „A nemzetközi jogot figyelmen kívül hagyó nagyhatalmi törekvések Európa és közvetve hazánk biztonságát is megkérdőjelezhetik. Az agresszióval kikényszerített területszerzés alapjaiban változtatta meg biztonsági környezetünket, jelentősen megnövelve az esetleges konfrontáció kockázatát. Továbbra is törekedni kell a párbeszédre, ugyanakkor készen kell állni az ellenünk vagy szövetségeseink ellen irányuló, akár figyelmeztetés nélkül, hagyományos vagy nem hagyományoseszközökkel végrehajtott agresszió elrettentésére és kivédésére is." ${ }^{45}$

\section{Kína}

Ugyancsak gazdaságpolitikai motivációjú a stratégia álláspontja Kínával kapcsolatban: „A magyar-kínai kapcsolatok pragmatikus alapokon történő intenzív erősítése, és kiváltképpen az európai, afrikai és ázsiai kontinenseket összekötő kereskedelmi kapcsolatok szorosabbra füzését célzó »modern selyemút« (»Övezet és Út Kezdeményezés«) programba történő, kölcsönös előnyökkel járó bekapcsolódás Magyarország érdeke.” Ez azonban kiegészül azzal - a transzatlanti szövetségi rendszerben egyértelmüen hangoztatott - racionális kockázatértékeléssel, miszerint „a gazdasági együttmüködés lehetőségeinek kiaknázása

44 1163/2020. (IV. 21.) Korm. határozat 118. pont.

45 1163/2020. (IV. 21.) Korm. határozat 52. pont. 
során tekintettel kell lenni azokra a kitettségből adódó tényezőkre is, amelyek a feltörekvő Kína a kritikus infrastruktúrába történő beruházásai, a legfejlettebb infokommunikációs technológia esetleges szállítójaként való megjelenése és általában a regionális befolyásának megerősödése révén keletkeznek". ${ }^{6}$

\section{Kiemelt biztonsági kihívások és kockázatok a stratégiában}

Az új nemzeti biztonsági stratégia, amely a globális biztonság terén romló tendenciával számol, ${ }^{47} 17$ kiemelt, a magyar nemzeti érdekek szempontjából jelentős biztonsági kihívást és kockázatot sorol fel. ${ }^{48}$ Ezek tematikusan csoportosítva a következők:

\section{Illegális migráció, idegen népesség Magyarországra telepítése}

2012-höz képest - a 2015-2016-os európai migrációs- és menekültválság hatására - a migráció megítélésében következett be a legnagyobb változás az új nemzeti biztonsági stratégiában. Az előző stratégia a migrációra olyan természetes, összetett jelenségként tekintett, amely „gazdasági és demográfiai előnyöket, valamint köz- és nemzetbiztonsági kockázatokat egyaránt magában rejt". ${ }^{49}$ Az új stratégia nem társít pozitív vonatkozásokat a migráció jelenségéhez, a tömeges, ellenőrizhetetlen és illegális migrációra pedig a romló biztonsági környezet egyik fö elemeként tekint, amely akár az európai kontinens biztonságát és stabilitását is veszélyeztetheti, sőt - ha nem sikerül megállítani - „hosszabb távon az európai civilizáció jövőjét is eldöntheti” a stratégia szerzői szerint. ${ }^{50}$ A probléma fontosságát a dokumentum nem csupán azzal jelzi, hogy az illegális migrációt a Magyarországot érintő kiemelt biztonsági kockázatok első helyén említi, ${ }^{51}$ de azzal is, hogy részletesen és több pontban is szól a jelenség kiváltó okairól (túlnépesedés, gyenge megtartóképesség az instabil államokban, polgárháborúk), lehetséges hatásairól a migrációs tranzit- és célországokra (intézményi-gazdasági gyengülés, a társadalmi kohézió csökkenése), illetve az illegális migráció más kihívásokra gyakorolt negatív hatásairól (a terrorizmus, a járvány- és egészségügyi kockázatok növekedése). ${ }^{52}$ A stratégia az illegális migrációt és migrációs válsághelyzetek súlyosbítását az államok és nem állami szereplők által folytatott hibrid hadviselés lehetséges eszközeként is megjelöli. ${ }^{53}$

A stratégia egyértelmüvé teszi azt is, hogy Magyarország kiemelten érdekelt az ellenőrizhetetlen migrációval szembeni sikeres nemzetközi fellépésben, ennek elősegítésére pedig a NATO és az Európai Unió fokozottabb szerepvállalásában az afrikai kontinens, a közel-keleti és a közép-ázsiai térségek stabilitásának erősítésében, a migrációs okok öszszehangolt helyszíni kezelésében, az EU határainak védelmében, az európai menekültügyi

\footnotetext{
1163/2020. (IV. 21.) Korm. határozat 119. pont.

1163/2020. (IV. 21.) Korm. határozat 47. pont.

1163/2020. (IV. 21.) Korm. határozat 124. pont a-q. alpontok.

1035/2012. (II. 21.) Korm. határozat 37. pont

1163/2020. (IV. 21.) Korm. határozat 44., 57., 143. pont.

1163/2020. (IV. 21.) Korm. határozat 124. a. pont.

1163/2020. (IV. 21.) Korm. határozat 58., 62., 64-67. pont.

1163/2020. (IV. 21.) Korm. határozat 58. pont.
} 
rendszer átalakításában, szigorításában, az embercsempészet elleni közös fellépésben, a kibocsátó-, tranzit- és befogadó országok együttmüködésében, és hogy Törökországra kulcsfontosságú partnerként tekint az Európába irányuló migrációs nyomás kezelésében. ${ }^{54}$ Világosan reflektál ugyanakkor a magyar kormány és az Európai Unió közötti vitákra is, egyértelművé téve, hogy Magyarország „nemzeti szuverenitásával ellentétesnek és elfogadhatatlannak tart bármely olyan törekvést, amely hontalanok vagy külföldi állampolgárok kötelezö betelepítését írja elö”, s hogy a magyar kormány szerint „a tömeges, ellenőrizetlen és illegális migrációt nem pusztán kezelni, hanem megállítani kelll". ${ }^{5}$

A migrációnak a kiemelt biztonsági kockázatok élére való helyezésével a stratégia jól tükrözi a magyar társadalom biztonság- és fenyegetettségpercepcióját, az erre vonatkozó 2019. decemberi reprezentatív kutatásunkban ugyanis a megkérdezettek a második helyre sorolták az ellenőrizhetetlen migrációt (36,6\%) azon tényezők közül, amelyek Magyarország biztonságára leginkább negatív hatással járnak. ${ }^{56}$

\section{Váratlan fegyveres támadás, instabilitás Magyarország közvetlen szomszédságában}

Bár sokak számára talán meglepő, hogy az új biztonsági stratégia a váratlan fegyveres támadás lehetőségét a magyar nemzeti érdekek szempontjából jelentős biztonsági kockázatok listájának második helyére sorolja, ${ }^{57}$ ezt három ok is indokolhatja. Elsősorban az a szándék, hogy a stratégia nagy hangsúlyt fektessen az Észak-atlanti Szerződés 5. cikke alá tartozó kollektív védelmi feladatokra és ezt a szövetséges államok felé is jelezze. A fegyveres támadás lehetőségének előresorolásával a magyar kormány az Észak-atlanti Szerződés Szervezetének newporti, varsói és brüsszeli csúcstalálkozóit követő kollektív védelmét erösítő szövetségesi lépések - a NATO keleti szárnyának megerősítése - mellett áll ki határozottan. Ezt kiegészítő motiváció lehet a „diplomatikus reagálás” a Krím-félsziget 2014-es jogellenes annexiója, illetve az Oroszország által támogatott kelet-ukrajnai szeparatista fegyveres konfliktus kapcsán, amelyek precedensjelleggel törték meg a hidegháború után kialakult európai biztonsági architektúra szilárdságába és garanciáiba vetett hitet. Végül harmadrészt látnunk kell azt is, hogy az ilyen jellegü stratégiai dokumentumok 8-10 évre elöre tekintenek, s figyelembe véve a 2012-es stratégia megjelenése óta eltelt időszak eseményeit, továbbá azt, hogy az új stratégia szerzői a globális biztonság terén romló tendenciával számolnak, már korántsem olyan meglepő, hogy a váratlan támadás lehetőségét is előbbre sorolták a biztonsági kockázatok között. Fontos ugyanakkor azt is jelezni, hogy egy Magyarország vagy szövetségesei ellen irányuló fegyveres támadást jelenleg kevéssé tartanak valószínünek. ${ }^{58}$

Még inkább érthető a fegyveres támadás lehetőségének előresorolása, ha figyelembe vesszük, hogy az új nemzeti biztonsági stratégia jelentős biztonsági kockázatokat felsoroló

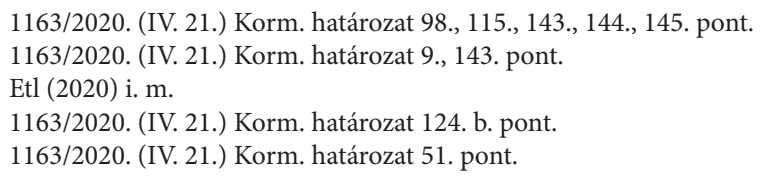


listáján ott találjuk a súlyos és tartós instabilitás kialakulásának, illetve „bukott államok” létrejöttének veszélyeit is Magyarország közvetlen szomszédságában. ${ }^{59} \mathrm{~A}$ dokumentum ugyanis továbbra is törékenynek és sebezhetőnek értékeli a nyugat-balkáni térség biztonsági helyzetét, $s$ Európa déli és délkeleti szomszédságát is olyan instabil és válságokkal terhelt térségként tartja számon, amelynek hatásai Magyarországot is elérhetik. Nem véletlen tehát, hogy alapvető magyar érdekként definiálja a stabilitás kivetítését, „kiemelten a nyugat-balkáni térségre". ${ }^{60}$

\section{A magyar szuverenitás és érdekérvényesítési képesség korlátozása, hibrid jellegü támadása}

A magyar szuverenitásfelfogásból és a nemzetközi rendszer többszereplős jellegéből fakadóan az új biztonsági stratégia hangsúlyosan, részletesen és több pontban is foglalkozik azokkal a jelenségekkel és törekvésekkel, illetve azokkal az állami és nem állami szereplőkkel, amelyek a stratégia szerint a hibrid (vagyis katonai és nem katonai eszközök kombinációját alkalmazó) hadviselés térnyerése következtében megkísérelhetik Magyarország destabilizálását, kormányzati cselekvőképességének, politikai stabilitásának és társadalmi egységének gyengítését, továbbá nemzetközi érdekérvényesítő képességének korlátozását. ${ }^{61}$ Az erre irányuló diplomáciai, információs és titkosszolgálati műveleteket, pénzügyi-gazdasági nyomásgyakorlást, pénzügyi spekulációs támadásokat vagy katonai fenyegetéseket a jelentős biztonsági kockázatok listájának harmadik helyére sorolja a stratégia ${ }^{62}$

A hibrid hadviselést, ennek kivédési képességét, illetve a hibrid müveletekkel szembeni ellenálló képesség fokozását az új stratégia több szempontból is kulcsfontosságúnak tekinti. Egyrészt, mert „ez a fajta hadviselési módszer elmossa a béke és a háború közötti éles határvonalat, nehezen áttekinthető, a háborús küszöb alatti, »szürkezónás «átmeneti állapotokat alakít ki”. ${ }^{63}$ Másrészt, mert a hibrid eszközök és módszerek egy részét a feltörekvő vagy újra megerősödő államok mellett a nem állami szereplők is alkalmazhatják (például az információs müveleteket, amelyek „,hatékonyságát növeli, hogy az álhírek, dezinformációk terjedését a közösségi média rendkívül gyorssá teszi”). Végül harmadrészt, mert a technológiai vívmányok proliferációjával „folytatódik a biztonságot veszélyeztetö, nehezen kontrollálható nem állami szereplők - például szervezett bünözői körök, nemzetközi terrorszervezetek, kiberbűnözői csoportok, szélsőséges vallási közösségek, magán biztonsági cégek, egyes nem kormányzati szervezetek és egyéb transznacionális hálózatok - súlyának növekedése a nemzetközi biztonságpolitikában". ${ }^{64}$

Hasonlóan az illegális migráció kérdésköréhez, a stratégia a szuverenitás és az érdekérvényesítési képesség korlátozása kapcsán is reflektál a magyar kormány nemzetközi vitáira. A kiemelt biztonsági kockázatok listájának f. pontja ugyanis „,a nemzeti szuverenitást sértő, a nemzeti döntési jogköröket nyíltan vagy leplezetten elvonó törekvéseket, továbbá

\footnotetext{
1163/2020. (IV. 21.) Korm. határozat 124. j. pont.

1163/2020. (IV. 21.) Korm. határozat 56., 67., 87. pont.

1163/2020. (IV. 21.) Korm. határozat 46., 58., 68., 69., 100. pont.

1163/2020. (IV. 21.) Korm. határozat 124. c. pont.

1163/2020. (IV. 21.) Korm. határozat 46. pont.

64 1163/2020. (IV. 21.) Korm. határozat 68-69. pont.
} 
a határon túli magyar közösségek helyzetének olyan jelentős romlását vagy ellehetetlenülését” is kiemelt kockázatként jelöli meg, „amelynek következtében tömegesen kényszerülhetnek elhagyni szülöföldjüket". 65

Fontos azonban jelezni, hogy ez a reflexió a stratégia egészét tekintve közvetett és diplomáciai szempontból körültekintő. Közvetett, mert a szuverenitással és a határon túli magyarok helyzetével kapcsolatos elvárások túlnyomó többségét a nemzeti értékek között sorolták fel, ${ }^{66}$ azok pedig, amelyeket nemzeti érdekként jelenít meg a stratégia, ${ }^{67}$ a napi politikai célok és taktikai megfontolások alá rendelt politikai kommunikációhoz képest kiegyensúlyozottak. Lásd például: „Magyarország szoros figyelemmel követi a szomszédos államokban élő magyarok helyzetének alakulását. Támogatjuk, hogy a határon túli magyarok közösségként, szülöföldjükön megmaradva élvezhessék az önkormányzatiság és az autonómia sajátos helyzetüknek leginkább megfelelö formáit” [...] „az ukrán nemzettudat erősítését szolgáló legitim törekvések nem járhatnak a kárpátaljai magyar közösség szerzett jogainak csorbulásával." ${ }^{8}$

\section{A kibertérrel és a technológiai vívmányok proliferációjával összefüggő kockázatok}

Miután 2013 márciusában elfogadták a Magyarország Nemzeti Kiberbiztonsági Stratégiáját, ${ }^{69} 2016$ júniusában pedig a NATO varsói csúcstalálkozóján a kiberteret a szövetség hivatalosan is operatív müveleti területként ismerte el, illetve kulcsfontosságú feladatként jelölte meg a kiberhadviselés fenyegetéseinek elhárításával és a kibervédelemmel összefüggő kutatásokat, és a tagállamok védelmi iparának e területen való együttmüködését, ${ }^{70}$ várható volt, hogy a 2012-es stratégiát leváltó új nemzeti biztonsági stratégia is alapvető biztonsági kérdésként kezeli a kiberfenyegetéseket és kiberbiztonságot. Nem véletlen tehát, hogy a dokumentum „a kormányzati informatikai rendszerek, az E-közigazgatás, a közmüszolgáltatók, a stratégiai vállalatok, a létfontosságú infrastruktúra egyéb elemei és más, a társadalom müködésében fontos szervezetek számítógépes hálózatai” elleni, jelentős károkat okozó kibertámadásokat a biztonsági kockázatok listájának negyedi helyére sorolta. ${ }^{71} \mathrm{Az}$ új biztonsági stratégiában 16 pont foglalkozik a kérdéskörrel vagy érinti azt, ${ }^{72}$ amelyek közül a 101-es - immár a NATO álláspontjával teljesen egyezően - úgy fogalmaz: „Magyarország a fizikai biztonságot veszélyeztető vagy jelentős anyagi károk okozására képes kiberképességeket fegyvernek, alkalmazásukat fegyveres agressziónak tekinti, amelyre a fizikai térben megvalósuló válaszadás is lehetséges.” A 106. pont pedig a kibervédelmet azon területek között jelöli meg, ahol kiemelt figyelmet kell fordítani „a kutatás-fejlesztésre

65 1163/2020. (IV. 21.) Korm. határozat 124. f. pont.

${ }_{66}$ 1163/2020. (IV. 21.) Korm. határozat 8-9., 11., 13., 15. pont.

67 1163/2020. (IV. 21.) Korm. határozat 83-84., 88., 96., 102. pont.

68 1163/2020. (IV. 21.) Korm. határozat 84., 88. pont.

69 1139/2013. (III. 21.) Korm. határozat Magyarország Nemzeti Kiberbiztonsági Stratégiájáról. [online], 2013. 03. 21. Forrás: kormany.hu [2020. 05. 24.].

70 Tálas Péter: A varsói NATO-csúcs legfontosabb döntéseiről. [online], Nemzet és Biztonság, 9. (2016), 2. 99. Forrás: nemzetesbiztonsag.hu [2020. 05. 24.].

71 1163/2020. (IV. 21.) Korm. határozat 124. d. pont.

72 1163/2020. (IV. 21.) Korm. határozat 8., 31-32., 48., 69-71., 101., 106., 136., 159-160., 162., 175., 178. pont. 
és annak védelmi összetevőire”. Fontos azonban jelezni, hogy védelmi összetevők mellett az offenzív képességek kialakítását is feladatként jelöli meg a stratégia, miként - hasonlóan a hibrid műveltekhez - kiemelt célnak tekinti a kibertámadásokkal szembeni „nemzeti ellenállóképesség fokozását" is. ${ }^{73}$

Az új biztonsági stratégia ugyancsak a kiemelt biztonsági kockázatok közé sorolja a forradalmi technológiai fejlesztések illetéktelen kezekbe kerülését, megállapítva, hogy „az emberiség technológiai szintjének rohamos fejlödésével [digitalizáció, ötödik generációs vezeték nélküli hálózat (5G), ürtechnológia stb.] folyamatosan új lehetőségek és kihívások jelennek meg, amelyek hatást gyakorolnak hazánk biztonságára" is. ${ }^{74}$ Az ebből eredő kihívásokkal szemben kétirányú fellépést tart szükségesnek a dokumentum. Egyrészt - kiindulva abból, hogy „a nemzetközi tudományos és technológiai versenyben elfoglalt helyünknek biztonságpolitikai jelentősége is van" -, a fokozott kutatás-fejlesztési aktivitást a legmodernebb technológia olyan kulcsfontosságú területein, mint a kibervédelem, a mesterséges intelligencia, az autonóm rendszerek, a biotechnológia és az ürtechnológia. ${ }^{75}$ Másrészt fokozott figyelmet fordít az ebből fakadó kockázatokra (így a feltörekvő Kína e területen történő beruházásaira és általában a vele való együttmüködésre is), ${ }^{76}$ illetve a védelmi képességek kialakítására azokkal szemben, akik e technológiát a nemzet biztonságát veszélyeztető támadásokra használhatják ki.

\section{A terrorizmushoz és a tömegpusztító fegyverek proliferációjához kapcsolódó kockázatok}

Miként 2001. szeptember 11. óta a legtöbb nemzeti biztonsági stratégia szerte a világban, de különösen a NATO és az Európai Unió tagállamaiban, az új magyar biztonsági stratégia is kiemelt kockázatként kezeli a terrorizmust, az ötödik legfontosabb helyre sorol$\mathrm{va}^{77}$ - amelyről megállapítja azt is, hogy „napjaink egyik legkomolyabb, nehezen előre jelezhető, aszimmetrikus fenyegetése, és közvetlen, hosszútávon fennmaradó veszélyt jelent a világ és ezen belül különösen Európa biztonságára"78 továbbá szintén kiemelt kockázatként kezeli a tömegpusztító fegyverekkel, illetve a nukleáris, radiológiai, biológiai vagy vegyi szennyezőanyagokkal végrehajtott támadások vagy terrorcselekmények lehetőségét. ${ }^{79}$ Fontos azonban jelezni, hogy miközben a stratégia e tekintetben is romló biztonsági környezettel számol, egyik említett kihívással kapcsolatban sem állapít meg aktuális és közvetlen fenyegetettségnövekedést Magyarországra vagy szomszédságára vonatkozóan, s elsősorban a kezelésükre való felkészülés fontosságát hangsúlyozza. ${ }^{80}$ Itt érdemes megemlíteni azt is, hogy a magyar biztonságpercepcióra vonatkozó kutatásunkban a megkérdezettek

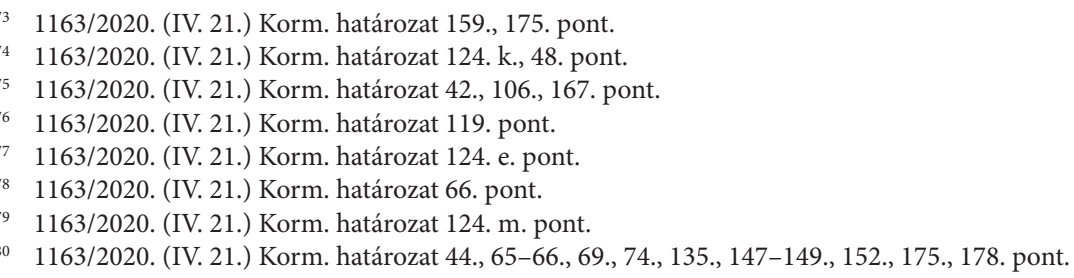


a negyedik helyre sorolták a nemzetközi terrorizmust (23,3\%) a Magyarország biztonságára leginkább negatív hatással járó tényezők között. ${ }^{81}$

\section{A magyar demográfiai folyamatokhoz kapcsolódó kockázatok}

A Biztonságos Magyarország egy változékony világban alcímet viselö új nemzeti biztonsági stratégia a kiemelt biztonsági kockázatok hatodik helyére sorolja a tartós népességfogyás és a lakosság átlagéletkorának folyamatos emelkedése miatti kritikus demográfiai helyzet kialakulásának lehetőségét. ${ }^{82}$ Bár a stratégiának mindössze 4 pontja foglalkozik a problémakörrel (6., 104., 156-157. pont), de a 104. pont egyértelművé teszi, hogy „Magyarország súlyos demográfiai problémáinak orvoslása össztársadalmi érdek és egyúttal egyik legfontosabb nemzeti ügyünk”. A népességfogyással és a társadalom elöregedésével küzdő keletés kelet-közép-európai államok biztonsági stratégiáihoz képest szokatlan - de a magyar kormány és a magyar társadalom migrációhoz való viszonya alapján érhető - módon ugyanakkor azt is egyértelmüen megfogalmazza, hogy „kiemelt nemzet- és családpolitikai cél a negatív demográfiai folyamat saját erőből, a nemzeti kultúra megtartásával történő megfordítása”. Ehhez „a felelős gyermekvállalást támogató családpolitikai intézkedések széles körét" tartja szükségesnek, továbbá bizonyos termelési folyamatok gépesítését, illetve mesterséges intelligenciával való megerősítését jelöli meg a demográfiai folyamatokból fakadó munkaerőhiány részmegoldásaként. ${ }^{83}$ Szemben ugyanakkor több más hasonló demográfiai helyzetben lévő állam biztonsági stratégiájával, a dokumentum a demográfiai kihívások kapcsán önállóan nem említi a lakosság egészségügyi állapotának megóvását (hosszabb, jobb minőségü, egészségeseb élet), és nem utal arra sem, hogy önálló népesedési stratégiára lenne szükség Magyarországon.

\section{A gazdasági és az energiabiztonság területén jelentkező kockázatok}

Tekintettel a magyar kormány 2011-ben meghirdetett és azóta egyértelmüen megerösödött gazdaságközpontú kül- és biztonságpolitikájára (ez utóbbinak kiváló aktuális példája a Zrínyi 2026 program, amely a haderőfejlesztési célok megvalósulását a hazai védelmi ipar fejlesztésével kívánja elérni), illetve a magyar gazdaságnak a világgazdaságba és különösen az európai termelési láncba való mély integráltságára, cseppet sem meglepő, hogy az új nemzeti biztonsági stratégia kiemelt biztonsági kockázatként kezeli a magyar gazdaságot és pénzügyi rendszert fenyegető potenciális veszélyforrásokat. Ezért a nemzetközi gazdasági válság kiújulását, a globális kereskedelmi konjunktúra tartós leállását, ennek következtében pedig a globális és regionális értékláncok leromlását az új stratégia a kiemelt biztonsági kockázatok közé sorolja. ${ }^{84} \mathrm{~A}$ dokumentum nem csak ennek okait jelzi („természeti erőforrásaink korlátozottak, külső tőkebefektetési szükségletünk és importfüggőségünk magas, a magyar gazdaságban az export meghatározó”, „Magyarország pénzügyi sebezhetősége

\footnotetext{
Etl (2020) i. m.

1163/2020. (IV. 21.) Korm. határozat 124. g. pont.

1163/2020. (IV. 21.) Korm. határozat 156-157. pont.

1163/2020. (IV. 21.) Korm. határozat 124. h. pont.
} 
az utóbbi években számottevően csökkent, a nemzetközi pénzpiacoknak való kitettségünk azonban kockázati tényezőt jelent”), ${ }^{85}$ de megnevezi azokat törekvéseket és célokat is, amelyekkel a magyar gazdaság ellenálló képességét kívánja javítani a kormány: „a tőkeerős, korszerű termelési technológiával rendelkező, versenyképes hazai vállalatok, kiemelten a kisés középvállalkozások, súlyának további növelése”, „a nemzetközi munkamegosztásban törekedni kell a globális értékláncok minél nagyobb hozzáadott értéket elöállító pontjaiba és munkafolyamataiba történő bekapcsolódásra, mivel ez a magyar gazdaság hosszútávon fenntartható növekedésének záloga” ${ }^{86}$ A magyar biztonságpercepcióra vonatkozó kutatásunkban egyébként a megkérdezettek az ötödik helyre sorolták a gazdasági sebezhetőséget $(21,4 \%)$ a magyar biztonságra leginkább negatív hatással járó tényezők között. ${ }^{87}$

A stratégia Alapvetö adottságaink címú fejezete annak okait is több pontban tárgyalja, hogy magyar energiabiztonsággal kapcsolatos veszélyforrások miért számítanak a kiemelt biztonsági kockázatok közé: „Jelenleg az egyik fö kihívás a földgázellátás tekintetében a 80\%-ot meghaladó importfüggőségünk, amely nemcsak ellátás biztonsági kockázatokat jelent, hanem kitettséget is az importárak alakulásának”, „a hazai lignit, barna- és feketeszén készlet az egyetlen itthon is rendelkezésre álló, nem megújuló energiaforrás”, „közvetlen tengeri kijárattal nem rendelkező országként, valamint a történelmi okokból egy irányban kialakított energetikai infrastruktúra következtében Magyarország energiaellátása tekintetében kiszolgáltatott". ${ }^{8}$ Érthető tehát, hogy a stratégia szerzői az energiaimportban bekövetkezett fennakadásból fakadó ellátási válsághelyzet létrejöttét is felvették a kiemelt biztonsági kockázatok listájára. ${ }^{89}$ Itt jelezzük azt is, hogy kutatásunkban a harmadik helyre került az ország gázfüggősége (29\%) a Magyarország biztonságára leginkább negatív hatással járó tényezők közül. ${ }^{90}$

A kormány legfontosabb energiapolitikai célkitüzéseiként a stratégia „az energiaszuverenitás és az energiabiztonság” megerősítését, az energiatermelés dekarbonizációját (fosszilis energiaforrások atomenergiával való kiváltását), az energiaellátási források és útvonalak diverzifikálását, az energiaimport-szükséglet csökkentését, illetve az integrált európai és regionális belső energiapiac kiépítésében való részvételt jelöli meg. ${ }^{91} \mathrm{Az}$ említett célok elérését biztosító legfontosabb eszközök között a földgáz új beszerzési és tranzitlehetőségeinek kiaknázását, az észak-déli irányú energia-infrastruktúra és határkeresztező gázvezetékek (interkonnektorok) kiépítését, az energiafelhasználás hatékonyságának növelését, a hazai megújuló energiák alkalmazását, a villamosenergia-szektor dekarbonizálásához pedig Paks 2 megépítését és üzembe állását jelöli meg a dokumentum. ${ }^{92}$

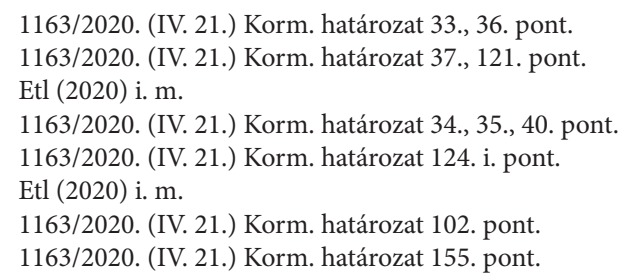




\section{A belsö biztonsághoz kapcsolódó kockázatok}

A belső biztonsághoz kapcsolódó kockázatok tematikus csoportjához az új biztonsági stratégia által a kiemelt kockázatok körébe sorolt két veszélyeztető tényezőt kapcsolthatunk. Egy hagyományosnak tekinthető kockázatot (a szervezett bünözést) és egy újat (járványok megjelenése és gyors terjedése).

A hagyományos kockázat kapcsán - „bünszervezetek, szervezett bünözői csoportok magyarországi térnyerése és befolyásának erősödése” - az új biztonsági stratégia tartalmi tekintetben a 2012-es stratégiában foglaltakat ismétli meg, illetve egészíti ki azzal a megállapítással, hogy „a virtuális térben létrejött platformok kitágították” a szervezett bünözői csoportok lehetőségeit. ${ }^{93}$ A szervezett bünözéssel szembeni fellépést eszközeként pedig „a rendvédelmi szervek (rendőrség és nemzetbiztonsági szolgálatok) és az igazságszolgáltatás nemzeti és nemzetközi szintü - kiemelten európai uniós - együttmüködésének szorosabbá tétele”, valamint az erőforrások hatékony felhasználása szerepel a dokumentumban. ${ }^{94}$ Elődjétől eltérően ugyanakkor, az új stratégia csupán egyetlen felsorolásban, a migrációval összefüggésben, tesz említést a kábítószer-kereskedelem problémájáról, ${ }^{95}$ amelynek a korábbi stratégia még önálló pontot szentelt. ${ }^{96}$

Az új típusú kockázat kapcsán pedig - „a lakosság tömeges és súlyos megbetegedésének kockázatát hordozó járványos betegség magyarországi megjelenése és gyors terjedése"97 - már a jelenlegi koronavírus-járványra is reflektál a stratégia, megállapítva, hogy a „járványhelyzet kialakulása nem csak egészségügyi válsághelyzetet eredményezhet, hanem - a járvány súlyosságától függően (érintettek száma, fertőzőképesség, halálozási ráta stb.) - messzemenően kihathat a biztonság legtöbb elemére, mint például a gazdasági, szociális, katonai stb. biztonságra is”. ${ }^{98}$ A járványügyi kockázat kezelésére vonatkozóan a stratégia 169. pontja úgy fogalmaz: „Kiemelt figyelmet kell fordítani az egészségbiztonságra, amely a magas szintü egészségügyi ellátás mellett magában foglalja a természeti vagy civilizációs eredetü közegészségügyi és járványügyi kihívásokkal szembeni operatív és hatósági reagáló képességet is. Szélsőséges esetben készen kell állni a haderő alkalmazására járványügyi válsághelyzet elhárítása érdekében (kitelepítésben és karantén fenntartásában történő részvétel, személyi mozgások ellenőrzése, migrációs és bűnözési hullám megfékezésében történő részvétel, katonai kórházak müködtetése stb.)." Mint azt az elmúlt hónapokban tapasztalhattuk, mindennek jogszabályi feltételeit már megteremtették, és számos intézkedést a gyakorlatban is „teszteltek” az illetékes szervezetek.

\section{A katasztrófahelyzetekkel összefüggő kockázatok}

A stratégia a kiemelt biztonsági kockázatok körében önálló pontokként szerepelteti az ipari katasztrófák jelentette kockázatokat - „olyan Magyarország, vagy szomszédos országok

\footnotetext{
93 1163/2020. (IV. 21.) Korm. határozat 124. 1., 79. pont.

94 1163/2020. (IV. 21.) Korm. határozat 151-152. pont.

95 1163/2020. (IV. 21.) Korm. határozat 65. pont.

96 1035/2012. (II. 21.) Korm. határozat 35-36. pont.

97 1163/2020. (IV. 21.) Korm. határozat 124. o. pont.

98 1163/2020. (IV. 21.) Korm. határozat 63. pont.
} 
területén bekövetkezett ipari balesetek és katasztrófák, amelyek regionális kihatásokkal járnak”, illetve a természeti katasztrófák kockázatait - „nagyobb ár- és kiterjedt belvizek kialakulása, valamint más természeti katasztrófák - hosszantartó aszályos időszakok, hő- és hideghullámok, heves viharok, pusztító erdő vagy vegetációtüzek - rendszeres bekövetkezése". ${ }^{99}$ Míg az előbbi esetében a katasztrófavédelmi és polgári válságkezelési szervek közötti együttmüködés erősítésére és a katasztrófakockázat csökkentésére helyezi a hangsúlyt, ${ }^{100}$ az utóbbi esetében ezek mellett külön pontban hívja fel a figyelmet az ökoszisztémák fokozott védelmére, a biodiverzitás megőrzésére, a lakosság egészséges ivóvízzel és géntechnológiával nem módosított élelmiszerrel történő ellátásához szükséges feltételek biztosítására, a levegőminőség javítására, a széndioxid-kibocsátás csökkentésére, valamint a közegészségügyi, illetve az állat- és növényegészségügyi szervek felkészültségének növelésére. ${ }^{101}$ A katasztrófavédelmi intézkedések nemzetközi dimenziójáról, a szövetségesi segítségnyújtásról ugyancsak rendelkezik a dokumentum 26. és 174. pontja.

\section{Az éghajlatváltozással összefüggő kockázatok}

A kiemelt biztonsági kockázatként számon tartott kihívások listáját a klímaváltozással összefüggő kockázatok - „a globális felmelegedés következtében tartósan vízhiányos időszakok rendszeres előfordulása, a talaj fokozatos kiszáradása és eróziója, valamint a vegetáció pusztulása egyes erősen sérülékeny hazai térségekben” - zárják. ${ }^{102}$ A dokumentum egészében öt pontban érinti az éghajlatváltozás problémáját (1., 44., 49., 131., 171. pont), amelyet a biztonsági környezet jövőbeni romlásának fontos tényezői között említ (1., 44. pont), megállapítva, hogy hatásai „különösen erősen jelentkeznek számos olyan térségben, amelyek más okok miatt eleve sérülékenyek, súlyosbítva a meglévő társadalmi és gazdasági problémákat”. ${ }^{103}$ Jóllehet a stratégia a kormány biztonságpolitikai céljai kapcsán úgy fogalmaz, hogy „a fenntartható társadalmi és gazdasági fejlődés, továbbá a természeti katasztrófák megelőzésének egyik kritikus feltétele az éghajlatváltozás hatásainak mérséklése” (131. pont), ${ }^{104}$ a kockázati lista utolsó helyére való besorolásával az éghajlatváltozás jelentőségét a magyar társadalomhoz képest alulértékeli a stratégia. A magyar biztonságpercepcióra vonatkozó 2019. decemberi reprezentatív kutatásunkban ugyanis a megkérdezettek leggyakrabban az éghajlatváltozást $(36,8 \%)$ és az ellenőrizhetetlen migrációt $(36,6 \%)$ nevezték meg a két, Magyarország biztonságára leginkább negatív hatással járó tényezőként. ${ }^{105}$

\section{A nemzeti ellenálló képesség megerősítése}

A 2020-as nemzeti biztonsági stratégia sok tekintetben „fejlettebb”, komplexebb, a modern kor kihívásainak jobban megfelelő stratégiai gondolkodásmódról árulkodik, mint a közel

\footnotetext{
99 1163/2020. (IV. 21.) Korm. határozat 124. n., p. pont.

100 1163/2020. (IV. 21.) Korm. határozat 142., 147. pont.

101 1163/2020. (IV. 21.) Korm. határozat 171. pont.

102 1163/2020. (IV. 21.) Korm. határozat 124. q. pont.

103 1163/2020. (IV. 21.) Korm. határozat 49. pont.

${ }_{104}$ 1163/2020. (IV. 21.) Korm. határozat 131. pont.

105 Etl (2020) i. m.
} 
egy évtizede alkotott dokumentumok. A már említett jellemzőkön túl ilyen „új elem” annak a célnak és elvárásnak a határozott megfogalmazása, hogy a változó biztonsági környezetben Magyarország mit és hogyan kíván elérni. Így a már megszokott és korábban is szakszerűen értékelt biztonsági környezet jelenlegi és jövőben elvárt statikus leírásán túl dinamikus elemek, a célok megvalósításának eszközei és módjai is megjelennek a stratégiában (még ha nem is egységesen mindenhol). Gyakorlatilag a IX. rész (132-175. pontok) fö rendeltetése éppen ez. Ilyen új elem az európai stratégiai gondolkodással összhangban az úgynevezett „ellenálló képesség” (resilience) megteremtésének, megerősítésének feladata.

Szélesebb értelemben természetesen ez több dolgot is magában foglal, így a megelőzés, valamint a gyors és határozott válaszadás képességét is. „Magyarország stratégiai célkitüzése, hogy 2030-ra kialakítsa azokat a nemzeti ellenálló, elrettentési, védelmi, válságkezelési és koordinációs képességeket, amelyek a változékony nemzetközi környezetben előfeltételei a nemzet fejlődéséhez szükséges stabilitásnak és biztonságnak." ${ }^{106}$ Mindezt - a válságkezelési mechanizmusoknak megfelelően - szövetségesi keretbe is helyezi a dokumentum: „Érdekeltek vagyunk a NATO és az EU nem hagyományos támadásokkal szembeni ellenálló és reagáló képességének fejlesztésében."107

Mint azt a kiemelt kockázatok és kihívások kapcsán korábban már jeleztük, az ellenálló képesség fokozása megjelenik még kiemelten a hibrid és kiberfenyegetések, a katasztrófák következményeinek kezelése, valamint egyes stratégiai erőforrások kezelése (nemzeti felügyelete, a függőség csökkentése) kapcsán, így az energia (34-35. és 40. pont), az ipar (37. pont), a mezőgazdaság és élelmiszer-biztonság (38. pont) és az édesvíz (39. pont) tekintetében.

A megvalósítás pedig általánosságban az államigazgatási/szakigazgatási és különös hangsúllyal a biztonsági szektor és védelmi szféra szereplöire esik, amelyek képességfejlesztéséről és kapacitásnöveléséről az NBS számos pontban (27-32., 134-135., 159-160., 165-166.) rendelkezik.

\section{A haderő szerepe}

Tekintettel arra, hogy külön ágazati katonai stratégia szokta követni az NBS-t, a jelenlegi dokumentumban a korábbi példákhoz képest igen hangsúlyos a honvédelem kérdése, ami egyébként a magyar szakpolitikák sorában is lényegesen „elörébb kerül” az elmúlt öt évben. (A nagyobb láthatóság abból is eredhet, hogy a Honvédelmi Minisztérium volt a stratégia "gazdája”.) A nagyobb hangsúlyt egyébként a 2020-as évekre elöre jelzett romló biztonsági környezet, a katonai erő felértékelödése és az egyre szélesebb honvédelmi feladatkörök (csak az elmúlt évekre gondolva a határellenőrzésben és az egészségügyi válsághelyzetben ellátott pluszfeladatok) is indokolják.

Az NBS feladatszabása e tekintetben egyértelmű kritériumokat határoz meg: „A Magyar Honvédségnek jól felszerelt és jól kiképzett erőkkel, valamint rugalmas, hatékonyan alkalmazható, telepíthető és fenntartható, a szükséges mértékben interoperábilis képességekkel kell rendelkeznie, a mennyiségi mellett a minőségi mutatók javítására törekedve.

106 1163/2020. (IV. 21.) Korm. határozat 126. pont.

107 1163/2020. (IV. 21.) Korm. határozat 129. pont. 
Hagyományos országvédelmi és nemzetközi válságkezelési feladatai mellett egyaránt alkalmasnak kell lennie a tömeges bevándorlás okozta válsághelyzet, vagy a terrorveszély-helyzet kezeléséhez történő hozzájárulásra, a hibrid támadások elhárításában való szerepvállalásra, valamint a természeti vagy ipari katasztrófák következményeinek felszámolásában való közreműködésre. A haderőt úgy kell fejleszteni, hogy képes legyen hatásokat kiváltani a hazánk szempontjából releváns összesműveleti térben: a szárazföldön, a levegőben és a kibertérben egyaránt." ${ }^{108}$ Ezt a széles képességspektrumot a Zrínyi 2026 Honvédelmi és Haderőfejlesztési Program fejlesztései, ${ }^{109}$ a katonai kibervédelmi képességek erősitése, ${ }^{110}$ valamint a magyar védelmi ipar fejlesztése ${ }^{111}$ hivatott biztosítani. A gyakorlati megvalósítás egyes kérdéseire a nemzeti katonai stratégia adhat majd bővebb választ.

\section{Hiányosságok}

Elismerve, hogy a 2020-as NBS mind funkcionalitásában, mind tartalmában lényegesen „erősebb”, mint elődjei, néhány aspektussal kapcsolatban hiányérzet merülhet fel az olvasóban. Ez elsősorban abból eredhet, hogy miközben az NBS összkormányzati bedolgozással készült, a biztonság egyes „mainstream” (például katonai) elemei, valamint a nemzetközi tapasztalatok alapján égetőbb aktuális kihívások (migráció, terrorizmus) mégis nagyobb hangsúlyt és láthatóságot kaptak.

A következő évtizedekre előre tekintve - miként azt a nemzetközi biztonsági környezet trendjei alapján elöre jelezhetjük - alapvető és megkerülhetetlen problémává fog válni a globális éghajlatváltozás és annak regionális hatásai, amire a stratégia is rámutat: „A globális felmelegedés és a szélsőségesebbé váló időjárás hozzájárul egyes államok belső nehézségeinek erősödéséhez. Az éghajlatváltozás hatásai mindenhol érzékelhetőek, ugyanakkor különösen erősen jelentkeznek számos olyan térségben, amelyek más okok miatt eleve sérülékenyek, súlyosbítva a meglévő társadalmi és gazdasági problémákat."112 Azonban többnyire elsiklik afölött, hogy nem csupán távoli sérülékeny térségekre, hanem a közép-európai térségre és kifejezetten Magyarországra milyen hatásai lehetnek, és e hatások mérséklését (mitigációját), vagy az alkalmazkodást (adaptációt) milyen eszközökkel és intézményi, gazdasági, sőt társadalmi kapacitásokkal tervezik megoldani. Különösen fontos lenne ez a mezőgazdaság termelékenységének biztosítása, pláne technológiai fejlesztése tekintetében, ami áttételesen számos stratégiai érdekhez hozzájárul, így például az élelmiszer-ellátás minősége és biztonsága, a hazai kis- és középvállalkozások erősítése, valamint a vidék társadalmi megtartóereje szempontjából. Hasonló társadalmi jelentősége lehet az éghajlatváltozás egészségügyi hatásainak. (Jegyezzük meg: a természeti katasztrófák és általában a katasztrófavédelem kérdését ebben az aspektusban átfogóan és mélyen lefedi az NBS.) Az éghajlatváltozáshoz kapcsolódó célok és intézkedések bővebb részletezését indokolná a magyar társadalom korábban már említett fenyegetettségpercepciója is.

\footnotetext{
108 1163/2020. (IV. 21.) Korm. határozat 27., 52., 134-135. pont.

109 1163/2020. (IV. 21.) Korm. Határozat 27-28. pont.

110 1163/2020. (IV. 21.) Korm. Határozat 159. pont.

111 1163/2020. (IV. 21.) Korm. Határozat 2., 5-6., 28-29., 105., 128., 136. pont.

112 1163/2020. (IV. 21.) Korm. határozat 49. pont.
} 
Sőt, a kérdés jelentőségéből adódóan egy, az NBS-en nyugvó, az éghajlatváltozás hatásainak kezelését célzó ágazati stratégia elkészítése is megfontolandó lenne. ${ }^{113}$

A stratégiakészítés fejlett országokra vonatkozó nemzetközi tapasztalataihoz mérten azt is érdemes jelezni, hogy az NBS nem nevezhető „emberközpontúnak” (miként a korábbi évek dokumentumai sem) - azaz sokkal inkább gondolkozik elvont kategóriákban („nemzet és szuverenitás”) és az ezeket érintő kihívásokban, mint a magyar társadalom kézzelfogható, ugyancsak a biztonságpolitika égisze alá tartozó problémáiban. Miközben rendkívül racionálisan határt szab a szociális ellátórendszer terhelését illetően - „a szociális biztonságnak a nemzetgazdaság teljesítőképességhez mért fenntartása"114 - nem jelenik meg a leszakadó, perifériára került társadalmi csoportok felzárkóztatása, a társadalmi különbségek lehetőség szerinti mérséklése, különösen a mélyszegénység és a társadalmi integráció problémái, amelyek nem szociális, hanem oktatási és gazdasági eszközökkel lennének kezelhetők. Márpedig a magyarországi cigányság gazdasági-társadalmi leszakadása akkor is stratégiai léptékü nemzeti kérdés lesz a 2020 -as években, ha nem nevezzük nevén.

Hasonlóképpen, elsősorban az oktatásra vonatkozóan jelenik meg a dokumentumban az az alapvető és modern szemlélet, hogy magát a magyar lakosságot tekintené stratégiai „erőforrásnak" - így egyes, a lakosság életminőségéhez, a társadalom fejlődéséhez és prosperitásához kapcsolódó kihívások is csak töredékesen jelennek meg, általában statikusan leírva és nem dinamikus megoldást kínálva. A társadalom demográfiai jellemzői például megjelennek problémaként, de az olyan elemek, mint az egészségtudatosság, egészséges életmódra nevelés, egészségmegörzés, nem egészítik ki az egészségügyi ellátás egyébként is kis szerepét, miközben ilyen módon lehetne elmozdulni a hosszabb, egészségesebb, minőségibb élet felé annak minden pozitív társadalmi és gazdasági hatásával.

\section{Összefoglaló}

A 2020 áprilisában közétett új magyar nemzeti biztonsági stratégiáról - amellyel a magyar politika régi adósságát törlesztette - az alábbiakat állapíthatjuk meg összefoglalóan:

- Magyarország új nemzeti biztonsági stratégiájának világképe reálpolitikai, és a globális biztonsági helyzet romló tendenciájával, biztonsági környezetünk jellemzőinek fokozatos romlásával számol a 2020-as évtizedben. Ugyanakkor azonosítja azokat a lehetőségeket is, amelyek elősegíthetik érdekeink érvényesítését.

- Helyzetértékelése az ország geostratégiai adottságaival kapcsolatban ugyancsak reális: számol a Közép-Európát érő nagyhatalmi befolyással, az ország kisállami jellemzőivel és korlátozott képességeivel, valamint stratégiai sebezhetőségeivel.

113 Az NBS záró rendelkezései között a 178. pontban szerepel olyan feladatszabás, amely akár ágazati stratégiák kidolgozására is vonatkozhat (de legalábbis a jogszabályi környezet felülvizsgálására és szükség esetén kiegészítésére): „A biztonság egyes részterületeiért felelős állami szervezeteknek a Magyarország Nemzeti Biztonsági Stratégiában megfogalmazott iránymutatásokkal összhangban kell megalkotniuk és felülvizsgálniuk a tevékenységükre vonatkozó szakági szabályzókat, különös tekintettel a nemzeti katonai, a rendészeti, a nemzetbiztonsági, a terrorelhárítási, a katasztrófavédelmi, a kiberbiztonsági és a migrációs területekre." Ezek között azonban az éghajlatváltozás nem szerepel. Az ágazati stratégiákra vonatkozóan pedig a kormányhatározat bevezetője ad támpontot, miszerint az NBS-ben foglaltak végrehajtását elősegítendő 2020. december 31-ig kell azokat felülvizsgálni, illetve elkészíteni.

114 1163/2020. (IV. 21.) Korm. határozat 104. pont. 
- Sok tekintetben „fejlettebb”, komplexebb, a modern kor kihívásainak jobban megfelelő stratégiai gondolkodásmódról árulkodik, mint elödjei. Funkcionálisan általában megvalósul a célok - eszközök - végrehajtók - végrehajtási módszerek egysége és az ezt alátámasztó elöíró szemlélet.

- 17 kiemelt biztonsági kihívást és átfogó szemlélettel számos más biztonsági célkitüzést azonosít.

- A kihívásokkal szemben a megelőzést, az ellenálló képesség fokozását, valamint a gyors és határozott válaszadás képességét helyezi a középpontba, és e képességek összkormányzati és szakpolitikai kialakításáról is intézkedik.

- A kiemelt partnerek között szerepelnek a visegrádi országok, illetve Lengyelország, Németország, az Egyesült Államok, Olaszország, Franciaország és Törökország.

- Jelentős a stratégiai célkitüzések gazdasági meghatározottsága és motivációja. Ambiciózus „kitörési pontként” jelenik meg az ürszektor és a hadiipar.

\section{FELHASZNÁLT IRODALOM}

Bibó István: A kelet-európai kisállamok nyomorúsága. Bibó István munkái V. Budapest, Argumentum Kiadó és Nyomda Kft., 2011.

Etl, Alex: The perception of security in Hungary. [online], ISDS Analyses, (2020), 3. Forrás: real.mtak.hu [2020. 05. 20.]

Etl, Alex - Tálas Péter: The transformation of Hungarian security perception between 1999 and 2019. [online], ISDS Analyses, (2020), 4. Forrás: svkk.uni-nke.hu [2020. 05. 20.]

Csiki Tamás: A stratégiai dokumentumok rendszere. [online], Nemzet és Biztonság, 1. (2008), 9. Forrás: nemzetesbiztonsag.hu [2020. 05. 24.]

Csiki Tamás: Az új Nemzeti Katonai Stratégia a nemzetközi tapasztalatok tükrében. [online], Nemzet és Biztonság, 7. (2014), 2, 45-61. Forrás: nemzetesbiztonsag.hu [2020. 05. 24.]

Csiki Tamás - Tálas Péter - Varga Gergely: A NATO walesi csúcstalálkozójának napirendje és értékelése. [online], Nemzet és Biztonság, 7. (2014), 4. 112-128. Forrás: nemzetesbiztonsag.hu [2020. 05. 24.]

Tálas Péter: A nemzeti katonai stratégia és a magyar stratégiai kultúra. [online], Nemzet és Biztonság, 7. (2014), 2. 3-16. Forrás: nemzetesbiztonsag.hu [2020. 05. 24.]

Tálas Péter: A varsói NATO-csúcs legfontosabb döntéseiről. [online], Nemzet és Biztonság, 9. (2016), 2. 97-101. Forrás: nemzetesbiztonsag.hu [2020. 05. 24.]

\section{Jogi források}

1035/2012. (II. 21.) Korm. határozat Magyarország Nemzeti Biztonsági Stratégiájáról. [online], 2012. 02. 21. Forrás: kormany.hu [2020. 05. 24.]

1139/2013. (III. 21.) Korm. határozat Magyarország Nemzeti Kiberbiztonsági Stratégiájáról. [online], 2013. 03. 21. Forrás: kormany.hu [2020. 05. 24.]

1163/2020. (IV. 21.) Korm. határozat Magyarország Nemzeti Biztonsági Stratégiájáról. [online], Magyar Közlöny, (2020), 81. Forrás: magyarkozlony.hu [2020. 05. 20.] 